\title{
Influence of environmental conditions on the virulence and distribution of Orobanche cumana Wallr. in the Republic of Moldova ${ }^{\text {ir }}$
}

\author{
Maria Duca ${ }^{1}$, Steliana Clapco ${ }^{1, *}$, Maria Nedealcov ${ }^{2}$ and Lidia Dencicov ${ }^{1}$ \\ ${ }^{1}$ Center of Functional Genetics, State University "Dimitrie Cantemir", Chisinau, Republic of Moldova \\ ${ }^{2}$ Institute of Geography and Ecology, Chisinau, Republic of Moldova
}

Received 17 July 2018 - Accepted 17 September 2018

\begin{abstract}
The parasitic angiosperm Orobanche cumana is present in the main sunflower-producing countries around the world. In recent years, more aggressive races of broomrape have evolved and the parasite has rapidly spread to new areas. A similar trend has been observed in the Republic of Moldova. At the beginning of $1950 \mathrm{~s}$, broomrape was detected in Moldova, especially in the southern areas. Currently, all the known races of Orobanche are present in the country and the parasite has expanded considerably on new areas in the center and north. Based on these results and the data reported by other authors, related to influence of climate change on the phytosanitary situation, we studied the interdependence between the climate and the distribution of Orobanche cumana Wallr. over different parts of the Republic of Moldova. Prevalence of broomrape infection mainly in the southern and central part of the Republic of Moldova and its sporadic presence in the northern part can be influenced, not only by short rotations, type of sunflower hybrids grown and soil parameters, but also by the weather conditions such as higher temperatures and lower humidity in the south and center. Based on multiannual data and trends observed in recent years, characterized by an increase in temperature and decrease of relative humidity, we conclude that climate change will create favorable conditions for infecting sunflower plants in all the areas where sunflowers are grown, including the expansion of broomrape to the north of Moldova.
\end{abstract}

Keywords: Orobanche cumana Wallr / sunflower / climate change / spreading / infestation

Résumé - Influence des conditions environnementales sur la virulence et la distribution de l'Orobanche cumana Wallr. en République de Moldavie. L'angiosperme parasite Orobanche cumana est présente dans les principaux pays producteurs de tournesol du monde. Ces dernières années, des races d'Orobanches plus agressives sont apparues et le parasite s'est rapidement étendu à de nouvelles zones. Une tendance similaire a été observée en République de Moldova. Au début des années 1950, l'Orobanche a été détectée en Moldavie, en particulier dans les régions du Sud. Actuellement, toutes les races connues d'Orobanche sont présentes dans le pays et le parasite s'est considérablement développé dans de nouvelles zones du Centre et du Nord. Sur la base de ces résultats et des données rapportées par d'autres auteurs, liées à l'influence du changement climatique sur la situation phytosanitaire, nous avons étudié l'interdépendance entre le climat et la distribution d'Orobanche cumana Wallr. sur différentes régions de la République de Moldova. La prévalence de l'Orobanche principalement dans le Sud et le Centre de la République de Moldova et sa présence sporadique dans la partie nord peuvent être influencées non seulement par les courtes rotations, le type d'hybrides de tournesol cultivés et les paramètres du sol, comme des températures plus élevées et une humidité plus faible dans le Sud et le Centre. Basé sur des données pluriannuelles et des tendances observées ces dernières années, caractérisé par une augmentation de la température et la diminution de l'humidité relative, nous concluons que le changement climatique créera des conditions favorables d'infection du tournesol par l'orobranche dans toutes les zones de cultivation, y compris l'expansion au nord de la Moldavie.

\footnotetext{
is Contribution to the Topical Issue "Sunflower and climate change / Tournesol et changement climatique"

*Correspondence: stela.clapco@gmail.com
} 


\section{Introduction}

Sunflower is the basic oilseed crop in the Republic of Moldova and one of the most popular among farmers. The favorable trend in oil prices, sustained by continuous production demands, has maintained increases in the areas sown to sunflower. Currently, sunflower has consistent planting areas, exceeding the admissible limits in crop rotations (Duca, 2015). This significant expansion is leading to an increase in the frequency and aggressiveness of various pathogens and especially of broomrape (Orobanche cumana Wallr.). Broomrape successfully competes with the sunflower for nutrient sources, thereby reducing sunflower yield by up to $50 \%$. These losses are dependent on genotype resistance, ontogenetic stage, duration of infection and climate conditions, which influence the infestation level (Dominguez, 1996; Alcántara et al., 2006).

Considering the economic importance of sunflower, technological management of Orobanche was and it still is - a high priority for Moldovan sunflower researchers. The role of crop rotation, soil adaptability, fertility management, climatic influence, crop water use, disease incidence etc. were studied at the Research Institute of Field Crops Selecţia, ASUM, MSU, making important scientific recommendations (Sharova, 1977; Buciuceanu et al., 1994; Vronschih et al., 2002; Duca et al., 2009; Rotarenco, 2010). Moreover, several breeding programs are conducted by private companies. As a result, during the last decades, in the Catalogue of Plant Varieties of the Republic of Moldova, 26 hybrids were registered, around 30\% being resistant to broomrape. However, the use of resistant cultivars, generally carrying single major genes for resistance, has been followed by the appearance of more virulent physiological races of parasite that overcome all known resistance genes (FernándezMartínez et al., 2010). The long-term success of breeding for broomrape resistance requires breeders to take into account geographical distribution, genetic variation and evolution of O. cumana.

The first documents that attest to the presence of broomrape in Moldova date back to 1863 just after the start of the sunflower crop in 1840. At the beginning of 1970s, a new broomrape race, called Moldovan race or race $\mathrm{C}$, was identified for the first time by Sharova (Sharova, 1977). Furthermore, a short historical investigation revealed the appearance of new physiological races of $O$. cumana in the Eastern part of Europe (former USSR) between 1970 and 1980 and only later the parasite migrated to Western Europe (Antonova, 2014). This data demonstrates co-evolution of the broomrape with its host, sunflower.

Russia was for many years the center of intensive breeding activities and VNIIMK varieties were cultivated (Škoric, 2016). Once Leclercq (1969, 1971) and Kinman (1970) discovered the cytoplasmic male sterility source and the corresponding restorer genes, the centers of intensive breeding programs are moved to Europe, subsequently broomrape became a limiting factor for sunflower development in Romania, Serbia, Bulgaria, Turkey and Spain (Molinero-Ruiz and Delavault, 2015).

Due to its geographical position at the border of former USSR and Western European countries, the Republic of Moldova represents a region of bidirectional flow of sunflower varieties and broomrape seeds. Currently, all the known races of Orobanche have been detected in Moldova. The areas affected by these parasitic plants expanded considerably across the territory of the country (Duca et al., 2017). At the beginning of $1950 \mathrm{~s}$, broomrape was detected in the southern areas of Moldova, migrating further to some fields in the center of the country (Duca, 2015). Based on the latest data, the parasite can also be found in newer areas in the center and north (Duca et al., 2015).

According to several authors, parasitic spread may be explained by the influence of biogeographical parameters, environmental factors (temperature, average rainfall, soil fertility) and the nutrients availability (Mohamed et al., 2006; Spallek et al., 2013). Considering that Moldova has a relatively small area (33 850 sq. km), without major geographical barriers (rivers, mountains) and with short distances between sunflower fields, it was both interesting and challenging to investigate and uncover the factors influencing the differential distribution and virulence of Orobanche cumana Wallr. in Moldova.

\section{Materials and methods}

The investigations were conducted in July-August, 2014, in a variety of locations from center, south and north of Moldova. Sampling was conducted using a mobile GPS. Each field investigated was divided into $10 \times 10 \mathrm{~m}$ square plots. Nine randomly selected plots from each group were analyzed. The number of plants attacked by broomrape and the number of broomrape stems per host plant were recorded in each plot. The frequency and intensity of the broomrape attack in natural conditions were calculated as described Kaya et al. (2004).

During the expeditions, fresh tissue and mature seeds of more than 40 populations of $O$. cumana parasitizing sunflower were collected. Simultaneously, soil samples were collected and the geographic coordinates of each sampling point were specified. Also, the state of sunflower farm fields was documented (type of hybrids grown, crop rotation, precedants, etc.) on the base of farmers' sociological survey. In order to establish the current racial structure of broomrape in Moldova, seeds collected were analyzed in greenhouse experiments, which were carried out using one susceptible genotype sunflower and 5 homozygous differentials carrying $\operatorname{Or} 5,6$ and 7 resistance genes as previously described (Duca et al., 2017).

To assess current and future risks of broomrape expansion, we analyzed the daily surface temperature and humidity data for all regions of Moldova between May and July 2014, as well as multiannual (1961-2014) data recorder by State Hydrometeorological Service of the Republic of Moldova. Geographic Information Systems were used as a research tool. For the interpolation of weather-climatic data the ArcGIS Program within the Spatial Analyst extension (the coordinate system is UTM WGS84 area 35N with central meridian 27) was applied. A multivariate regression analysis software package, STATGRAPHICS Centurion XVI was used. Among the physical and geographic factors taken into account (geographic latitude and longitude, absolute and relative elevation, slope orientation and exposure), the absolute elevation and slope were significant for the obtaining of regression models. Automatically generated maps were overlapped with the digital map representing points of broomrape outbreaks. 


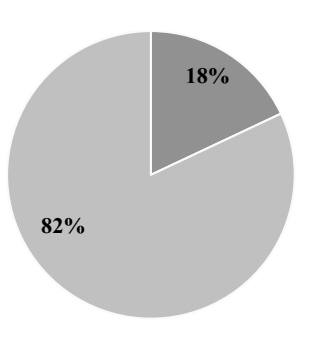

A.

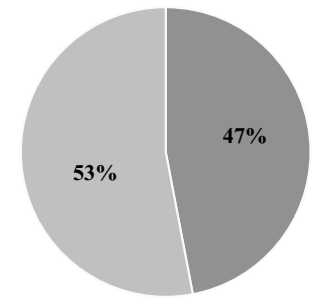

B.

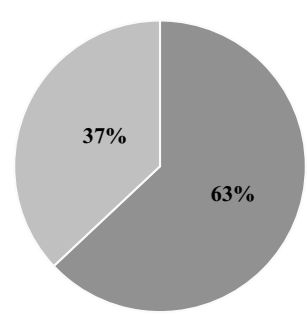

C.

Fig. 1. The rate of fields naturally infected by Orobanche cumana Wallr. in different parts of Republic of Moldova (A-North, B - Centre and C-South).

\section{Results and discussion}

During the expeditions conducted in July 2014 in 25 administrative districts from different parts of the country, it was concluded that broomrape infection was most widespread in central and southern regions of Moldova, the frequency and intensity of broomrape attack being higher in the south: broomrape was present in 14 of 22 localities analyzed (63\%) from the south, 17 of 36 localities (47\%) from the central part and only in 4 of 22 localities (18\%) in the northern regions (Fig. 1).

Furthermore, in about $50 \%$ of southern locations analyzed, the frequency of attack was $60-80 \%$, while in central part the maximum frequency was $40 \%$, in most cases about $10 \%$ (Duca, 2015; Duca et al., 2015, 2016). So, the presence and intensity of broomrape attack in sunflower fields decrease from southern to northern parts (Fig. 2). In the south the broomrape infestation was very high, causing critical damage to sunflower production.

Our previous results, based on phenotypic screening, revealed that populations collected from the central part of the republic were less virulent, mostly belonging from race $\mathrm{E}$ or $\leq \mathrm{E}$ (about $65 \%$ ), while populations in the southern and northern regions were characterized by increased virulence, more than $60 \%$ of them being classified as aggressive races $G$ and $\mathrm{H}$ (Fig. 3) (Duca et al., 2017).

This variation in race distribution and degree of attack for each field analyzed may result from control measures involving well-organized crop rotation, use of herbicides and of broomrape resistant hybrids, which are known to be effective in protection against the parasite (Habimana et al., 2013).

According to the farmers' social survey data, the rules of crop rotation are generally respected so more intense sunflower cropping and reduction of theoretically based crop rotations of 6-7 years to $1-3$ years have been introduced only in $15 \%$ of fields analyzed in all three regions, including $4 \%$ when sunflower was grown where it had been grown the year before (Fig. 4).

It is important to highlight that a majority of hybrids grown, produced by Pioneer, Saaten Union, Syngenta, NARDI Fundulea, are known to be resistant to broomrape.

Considering the importance of pedoclimatic factors in spread and evolution of broomrape in sunflower crop, the physical and chemical parameters of the soil (humus, nitrogen, phosphorus and mineral elements content, $\mathrm{pH}$, humidity, etc.) were analyzed. In most fields, the frequency of broomrape was positively influenced by high humus content and $\mathrm{pH}$ and negatively impacted by high potassium concentration. Samples from southern districts were characterized by higher $\mathrm{pH}$ (7.8-8.3), compared to 7.3-8.0 in the central part (Duca et al., 2016). It is known that slightly acid to neutral $\mathrm{pH}$ offers best conditions for broomrape development (Lyra et al., 2016), which could explain the preferential distribution of the parasite in the south. At the same time Miladinovic et al. (2012) concluded that soil texture, fertility and $\mathrm{pH}$ were not generally critical for broomrape presence.

Some authors reported that seed germination and development of $O$. cumana are highly dependent on climate (Song et al., 2005; Ephrath and Eizenberg, 2010) and actual climate change, characterized by increased temperatures and absence of rainfall could influence the expansion of Orobanche to large areas (Mohamed et al., 2006; Maširevic and MedicPap, 2009; Vear, 2016). Temperature requirements for parasite development differ among species, e.g. for $O$. crenata the optimum of temperature was found to be around $18^{\circ} \mathrm{C}$, lower and higher values decreased germination (Kasasian, 1973). Higher value of optimal temperature for conditioning and germination were reported in the case of $O$. cumana: $20-25^{\circ} \mathrm{C}$ (Kaya, 2016), O. cernua: $23-26^{\circ} \mathrm{C}$ and up to $28^{\circ} \mathrm{C}$ for $O$. ramosa (Nandula et al., 1996). The duration of temperatures required to promote seed conditioning usually are described in a range of $4-12$ days at a temperature of $19-23{ }^{\circ} \mathrm{C}$, in dark and humid conditions (Gibot-Leclerc et al., 2004; Lechat et al., 2012). Temperature significantly influences, also, the elongation of broomrape radicle (Nandula, 1998).

According to Sukno et al. (2001), broomrape populations are able to infect sunflower at a wide range of temperatures below $27^{\circ} \mathrm{C}$, with variation depending on the sunflower line-broomrape population combination. Eizenberg et al. (2003) reported that effects of temperature on $O$. cumana are complex. At higher temperatures $\left(27^{\circ} \mathrm{C}\right)$ the resistant varieties were more resistant to broomrape attack than at lower temperatures. Lower temperatures $\left(15^{\circ} \mathrm{C}\right)$ slowed parasite development in both resistant and susceptible varieties (Eizenberg et al., 2003).

Thus, the development and higher level of infection in south and central part of the Republic of Moldova could be due to the increased temperature in these regions compared to northern parts. The annual growth rate of broomrape varied 


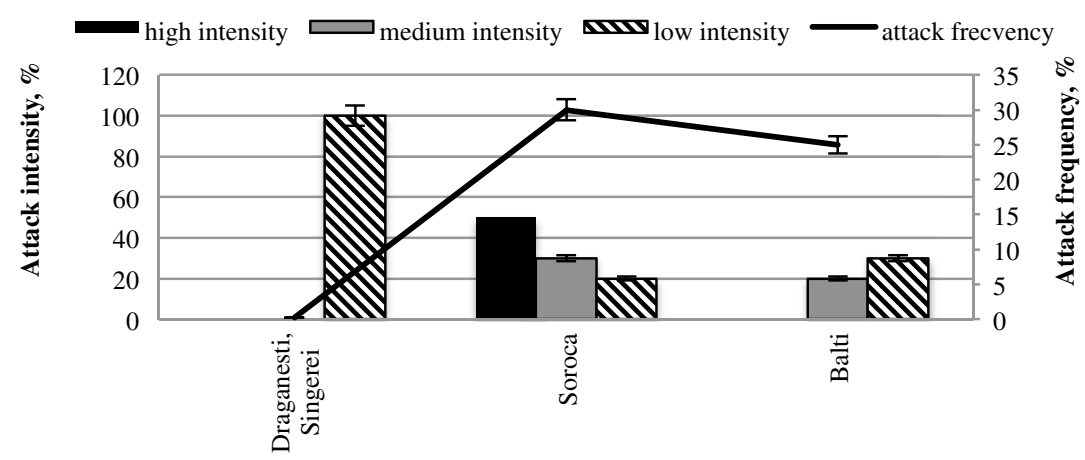

A.

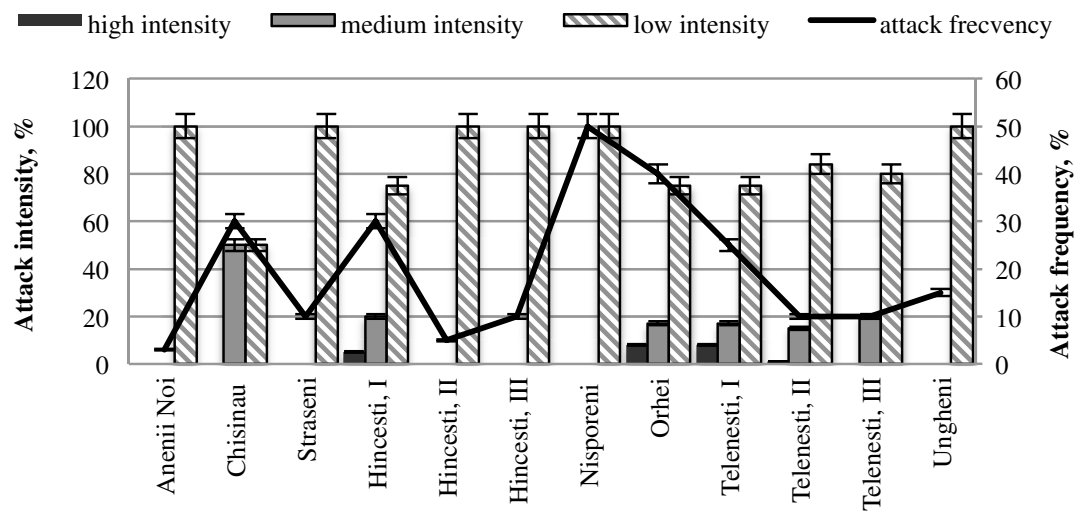

B.

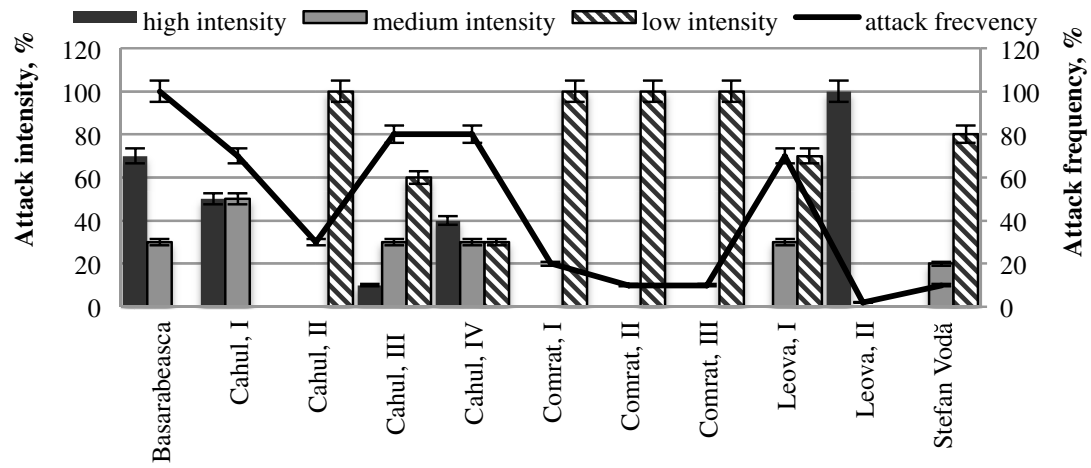

C.

Fig. 2. Virulence of broomrape collected from different part of the Republic of Moldova (A-North, B-Centre and C-South).

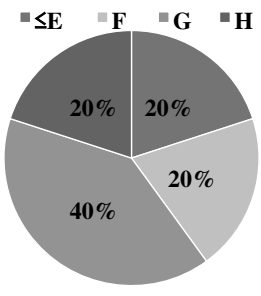

A.

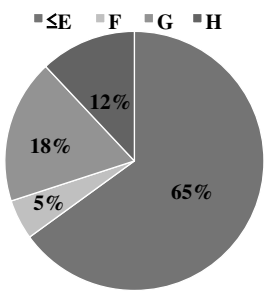

B.

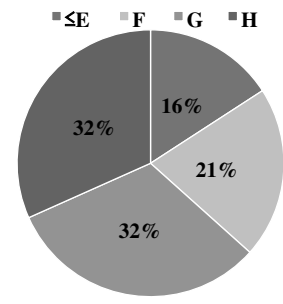

C.

Fig. 3. Race 1 structure of broomrape from the territory of Republic of Moldova (A-North, B-Centre and C-South). 


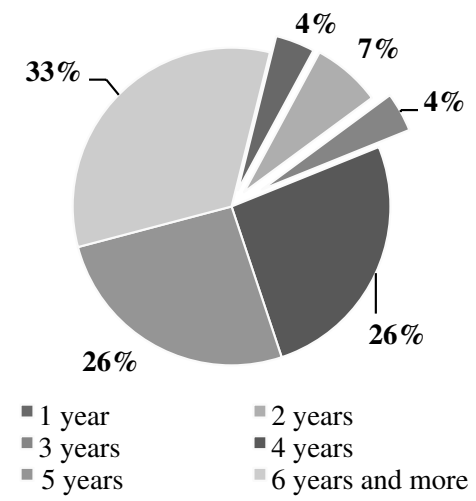

A.

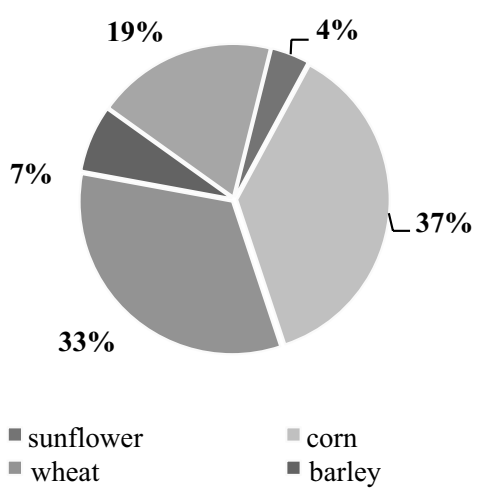

B.

Fig. 4. Rotation of sunflower in the infected fields (A-Crop rotation, B-Precedants).

Table 1. The variation of air temperature and humidity values in different region of Moldova during May-July 2014.

\begin{tabular}{|c|c|c|c|c|c|c|c|c|}
\hline Month & 10-day period & Zone & \multicolumn{3}{|c|}{ Temperature, ${ }^{\circ} \mathrm{C}$} & \multicolumn{3}{|c|}{ Humidity,\% } \\
\hline \multirow[t]{7}{*}{ May } & \multirow[t]{3}{*}{1} & North & 8.4 & 15.6 & 12.9 & 47 & 86 & 57.8 \\
\hline & & South & 9.7 & 16.5 & 13.6 & 56 & 91 & 73.5 \\
\hline & & Center & 10.5 & 16.1 & 13.5 & 46 & 89 & 65.1 \\
\hline & 2 & North & 11.9 & 18.5 & 14.6 & 64 & 90 & 71.9 \\
\hline & \multirow[t]{3}{*}{3} & North & 13.4 & 22.1 & 19.3 & 48 & 95 & 65.3 \\
\hline & & South & 14.8 & 22.3 & 19.6 & 68 & 93 & 75.4 \\
\hline & & Center & 16.8 & 23.8 & 20.6 & 48 & 89 & 64.9 \\
\hline \multirow[t]{6}{*}{ June } & 1 & North & 12.5 & 22.5 & 18.5 & 62 & 92 & 75 \\
\hline & \multirow{2}{*}{2} & South & 16.0 & 22.2 & 18.9 & 61 & 95 & 73.3 \\
\hline & & Center & 15.5 & 21.9 & 19.0 & 50 & 86 & 59.6 \\
\hline & \multirow[t]{3}{*}{3} & North & 13.2 & 20.6 & 16.7 & 51 & 90 & 65.7 \\
\hline & & South & 16.7 & 22.0 & 19.6 & 56 & 77 & 66.9 \\
\hline & & Center & 18.4 & 21.0 & 19.0 & 47 & 78 & 56.7 \\
\hline \multirow[t]{5}{*}{ July } & \multirow[t]{3}{*}{1} & North & 16.9 & 23.3 & 19.7 & 53 & 80 & 65.0 \\
\hline & & South & 18.3 & 24.2 & 22.1 & 50 & 80 & 65.3 \\
\hline & & Center & 18.4 & 24.7 & 22.2 & 45 & 76 & 56.0 \\
\hline & \multirow[t]{2}{*}{2} & North & 17.6 & 21.7 & 19.7 & 65 & 91 & 78.0 \\
\hline & & South & 20.7 & 23.0 & 21.8 & 63 & 86 & 76.2 \\
\hline
\end{tabular}

between years and was significantly correlated with temperatures in certain months (Cohen et al., 2017). We therefore analyzed climate data (temperature and humidity) for all regions of Moldova between May and July 2014 - the period of sunflower growth and the most favorable period for broomrape development (Tab. 1). 


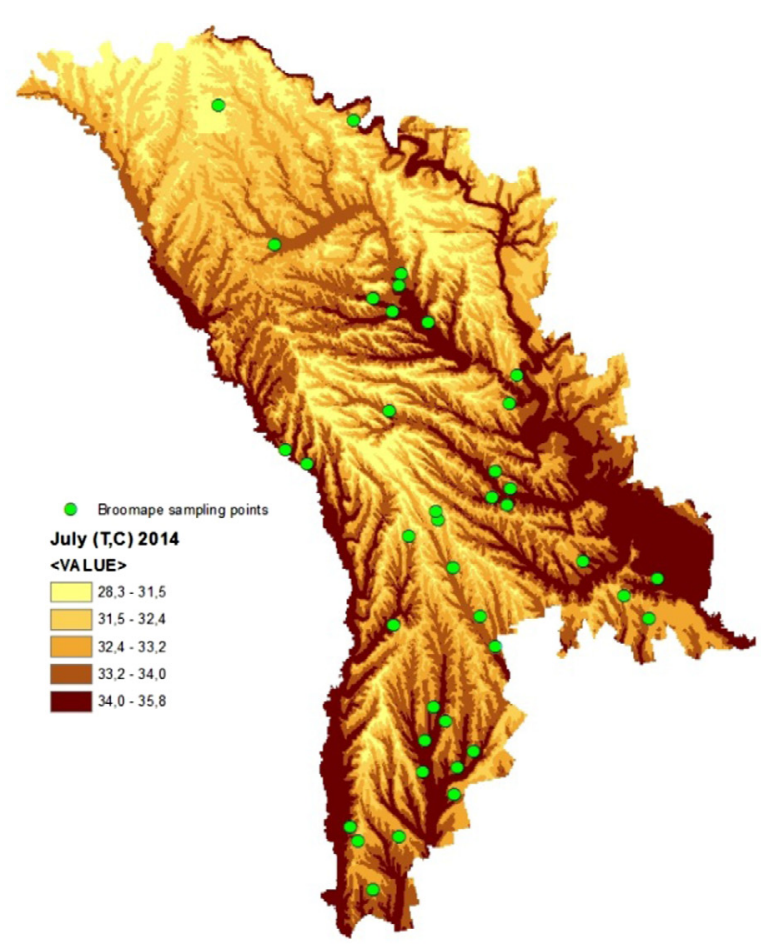

A.

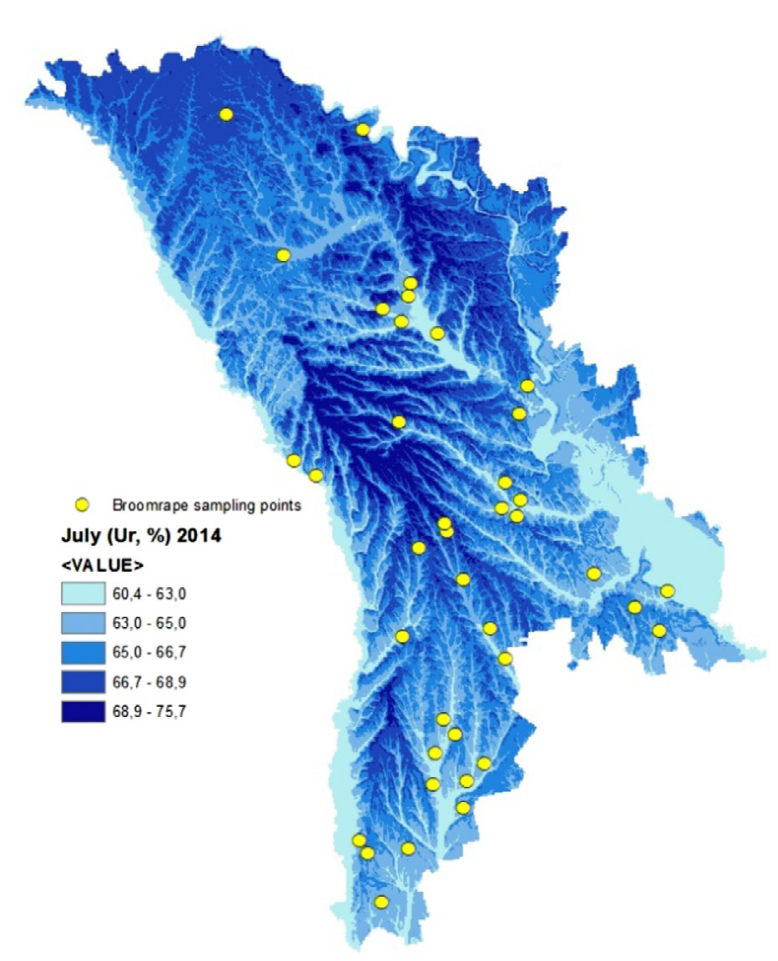

B.

Fig. 5. Cartographic modeling of temperature (A) and relative humidity (B) in July 2014.

In the first and middle part of May, mean temperature varied between $12.9-16.1^{\circ} \mathrm{C}$ with maximum in the south and minimum in the north part of the country. At the end of the month, the highest average value $-20.6^{\circ} \mathrm{C}$ was observed in the center of Moldova, followed by $19.6{ }^{\circ} \mathrm{C}$ in south and $19.3^{\circ} \mathrm{C}$ in the north. A similar tendency was typical also for the first and middle part of June, as well as for July, in the south and center part the temperature being higher with 2.0 $2.9^{\circ} \mathrm{C}$ than in the north. Thus, in June the average temperature ranged between $16.7-18.5^{\circ} \mathrm{C}$-in north, $18.9-20.2^{\circ} \mathrm{C}-$ in south and $19.0-20.5^{\circ} \mathrm{C}$-in Center and in July the temperature varied as follow: $19.7-21.5^{\circ} \mathrm{C}$-in north, $22.4-24.4{ }^{\circ} \mathrm{C}-$ in Center and $21.8-24.1^{\circ} \mathrm{C}-$ in south. The maximal temperature in these months $\left(24.4^{\circ} \mathrm{C}\right.$ in June and $26.6{ }^{\circ} \mathrm{C}$ in July) also was observed in Central part. southern and Central parts of Moldova are also characterized by lower humidity comparative to north part.

The higher temperature and lower humidity observed in south and center could improve germination and attachment of broomrape to the sunflower roots and could be an explanation of differential level of infestation between different zones (Fig. 1). Similarly, Louarn et al. (2016) supposed that higher level of broomrape infection in Cordoba in 2015 compared to 2014 could be due by the increased temperature (Louarn et al., 2016). Several studies have shown that Orobanche cumana attack of sunflower is positively correlated with temperature during germination, attachment and tubercle-production stages. Parasite development is enhanced at high temperatures and delayed by low temperatures (Ephrath and Eizenberg, 2010).

To permit visualization of broomrape populations in different areas, we mapped spatial distribution using comput- erized techniques (Fig. 5). We overlapped the outbreaks $O$. cumana with the distribution of temperature and humidity across the Republic of Moldova. As a result, we established that the main areas where $O$. cumana is spread coincide with higher temperatures and lower humidity.

Maps representing the spatial distribution of the broomrape outbreaks could be useful for correct zonation of sunflower hybrids and parasite control and monitoring.

To assess current and future risks of broomrape expansion, we analyzed multiannual data (1961-2016) and highlighted trends specific to recent years, characterized by an increase in temperature (Fig. 6) and a decrease of relative humidity (Fig. 7).

Considering the increase in average temperatures in July in the Republic of Moldova during 1961-2014 (Fig. 6), we can conclude that favorable conditions for spreading of this parasite will be maintained in the near future. Although in the north part of the country (Fig. 6A) the multiannual average temperature in July is $19.6^{\circ} \mathrm{C}$, i.e. $2.20^{\circ} \mathrm{C}$ and $2.30^{\circ} \mathrm{C}$ less than in the central (Fig. 6B) and south part (Fig. 6C), the temperature here increases faster compared to the rest of the territory $\left(0.0607^{\circ} \mathrm{C} /\right.$ year $)$. This could mean that the favorable temperature for the spread of broomrape could be reached faster.

The relative air humidity in July shows a downward trend during 1961-2016. Although the multiannual average values in the north are greater, i.e. $70.4 \%$, compared to the rest of the country, where the multiannual average varies between $62.2 \%$ (center) and 63.2\% (south); the humidity in the northern part of the country is decreasing significantly by about $0.0363 \%$ per year (Fig. 7A-C). 


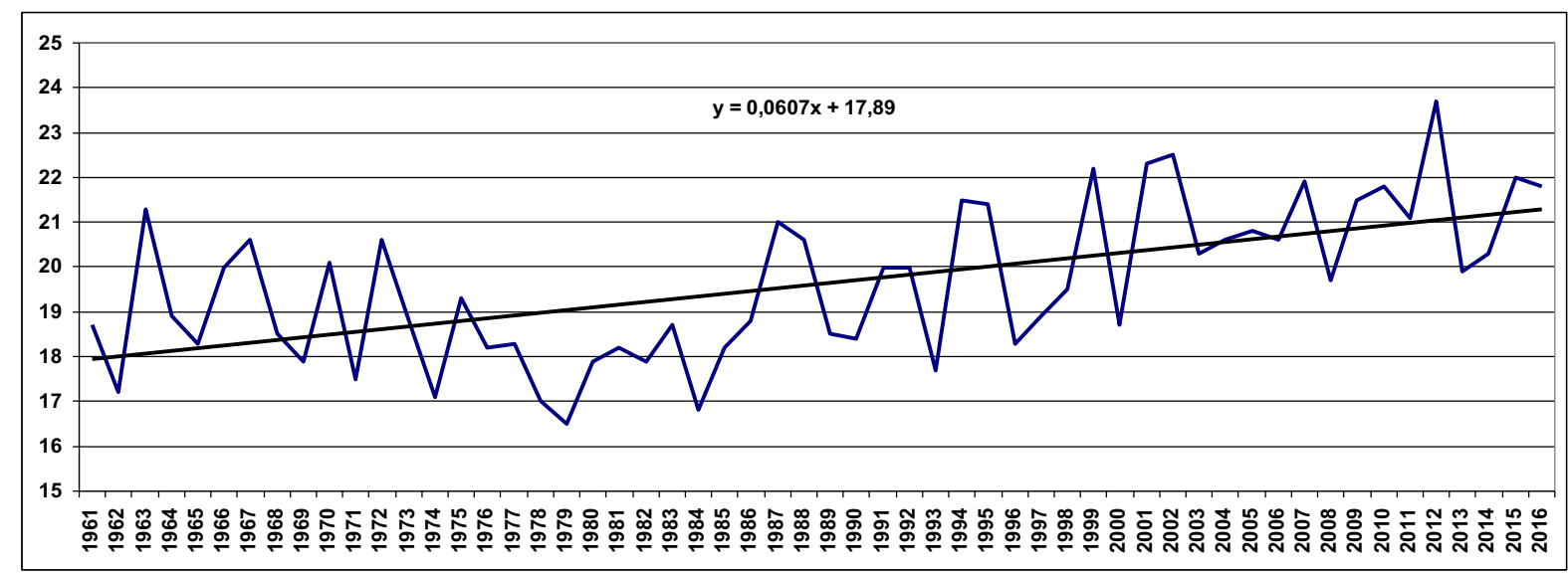

A.

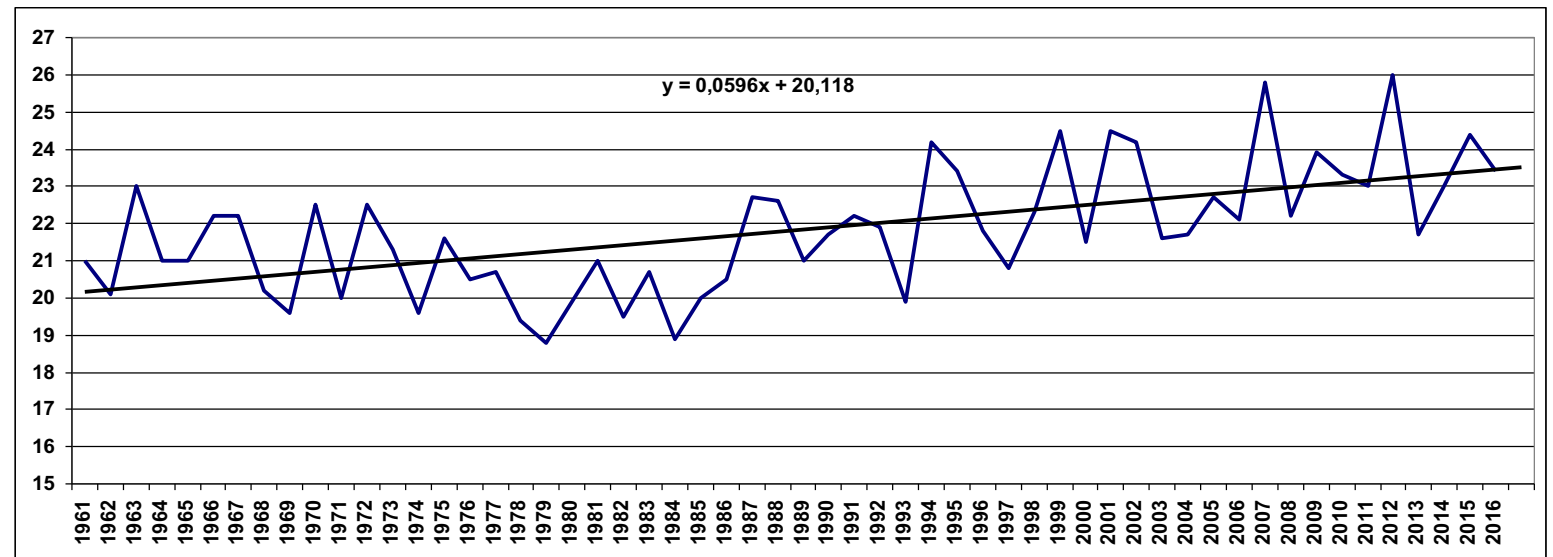

B.

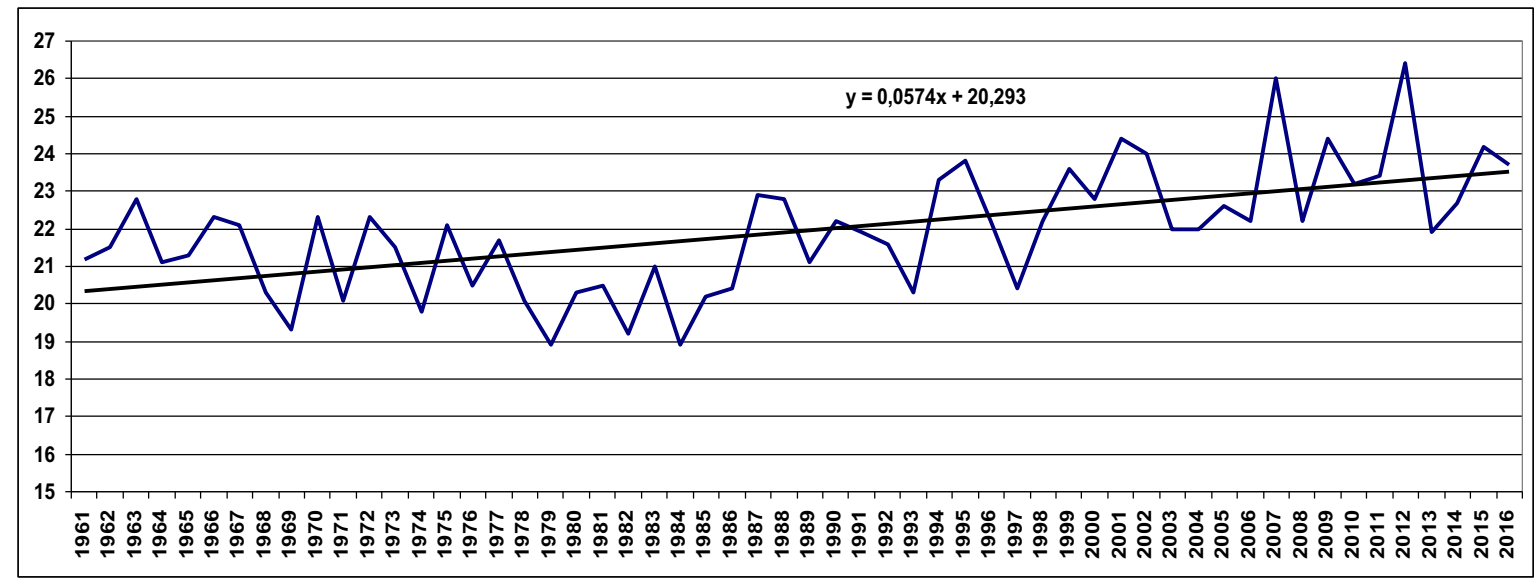

C.

Fig. 6. Dynamics of monthly (July) average temperatures on the territory of the Republic of Moldova (A - North, B - Center, C - South) between 1961 and 2016.

\section{Conclusions}

This study indicates that the persistence climate change could potentially create favorable conditions for infecting the sunflower in all areas, including the expansion of broomrape to the north of Moldova.
We conclude that the prevalence of broomrape infection mainly in the southern and central part of the Republic of Moldova and its sporadic presence in the northern part can be influenced, not only by short rotations and sunflower cultivars, but also by weather conditions such as higher temperatures and lower humidity in the south and center. 


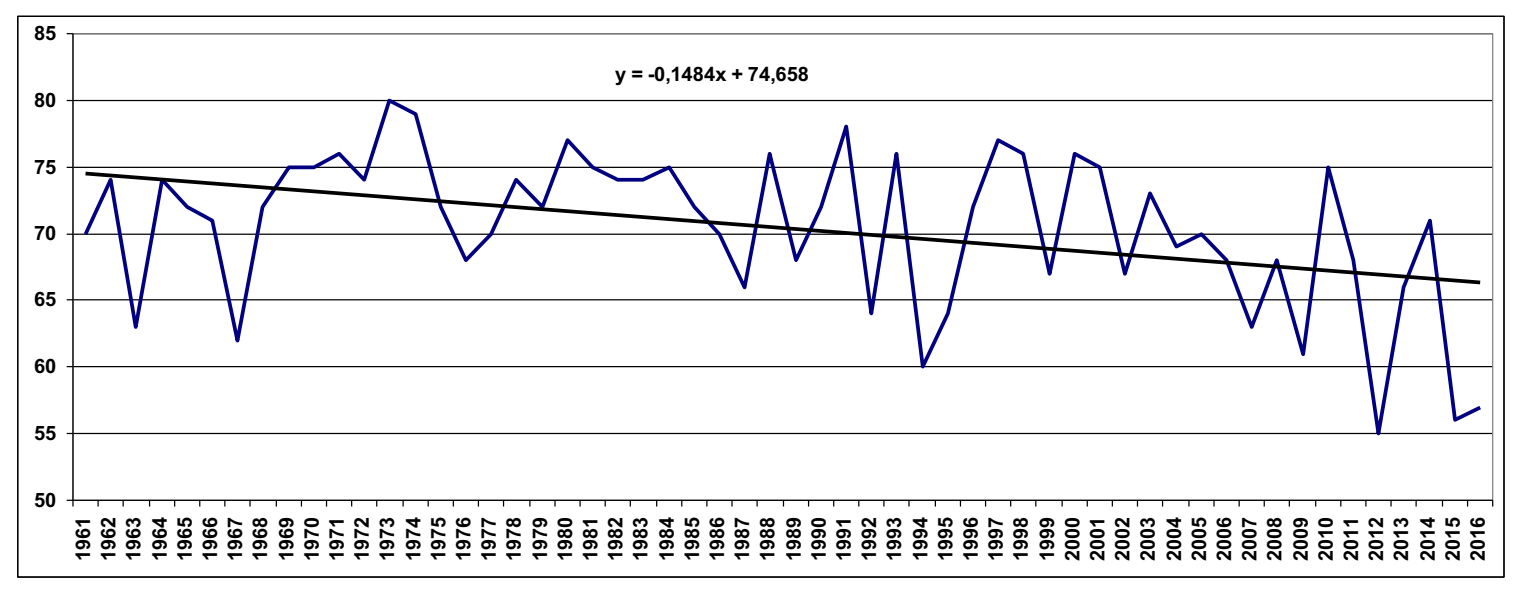

A.

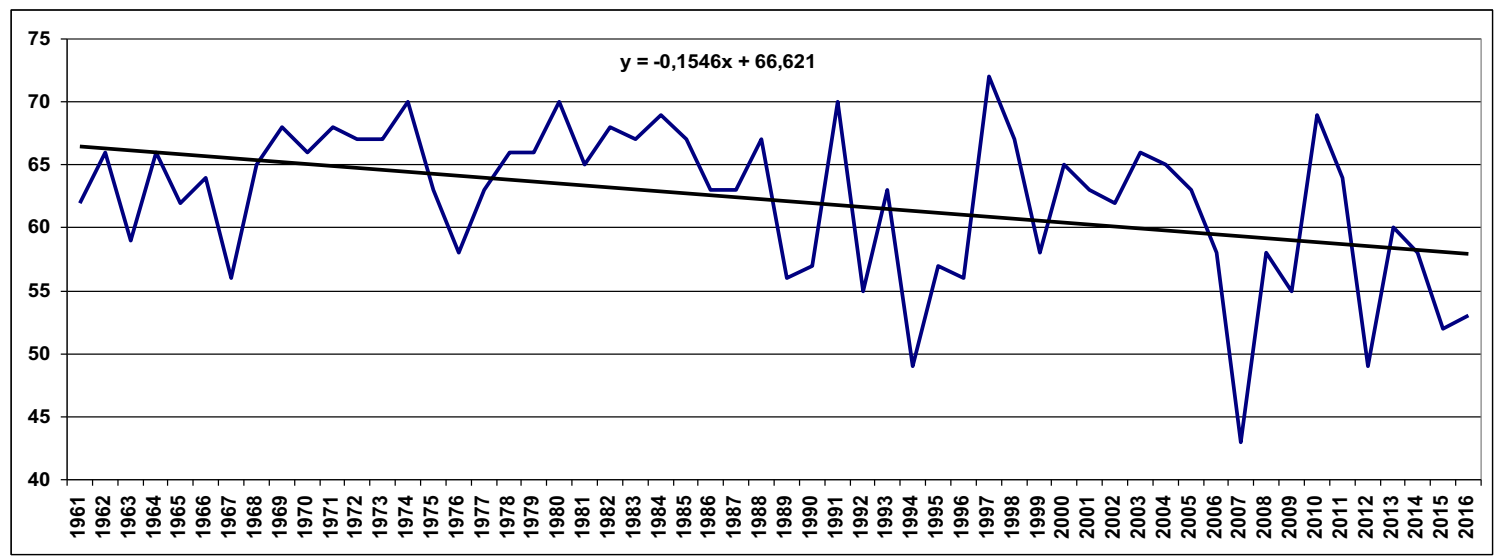

B.

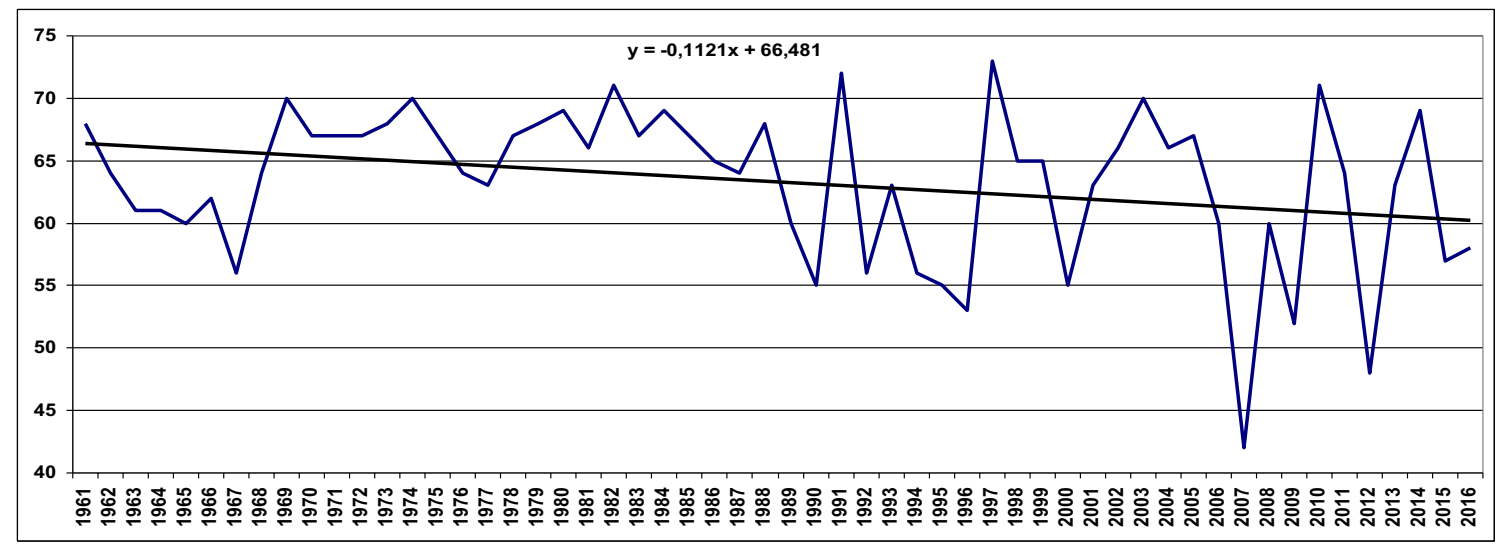

C.

Fig. 7. Dynamics of monthly (July) average relative humidity on the territory of the Republic of Moldova (A-North, B - Center, C-South) between 1961 and 2016.

Thus, over the years, these conditions could have contributed to the development of the parasite in these areas. Based on the multiannual data and the trends observed recently, characterized by the increase of the temperature and the decrease of the relative humidity, we can conclude that climate change will create favorable conditions for infecting sunflower plants in all cropping areas, including the expansion of broomrape to the north of Moldova.

Since early (winter) sowing of sunflower hybrids susceptible to the holoparasite leads to a significant reduction 
in Orobanche infection (Castejon-Munoz et al., 1993), and temperatures exceeding $40^{\circ} \mathrm{C}$, with increased moisture content, are lethal for broomrape seeds (Habimana et al., 2013), these conditions could be exploited as an effective parasite control technique (Mauromicale et al., 2001). Our data on the influence of environmental conditions could be used in establishing the optimum sunflower sowing period, sunflower zonation and diversifying of strategies for pathogen control.

Acknowledgments. This study was supported by the project funded by Supreme Council of Science and Technological Development of Academy of Sciences of Moldova. We also thank the team of Institute of Ecology and Geography and the State Hydrometeorological Service of the Republic of Moldova that provided the temperature and humidity data.

Conflicts of interest. The authors declare that they have no conflicts of interest in relation to this article.

\section{References}

Alcántara E, Morales-García M, Díaz-Sánchez J. 2006. Effects of broomrape parasitism on sunflower plants: growth, development, and mineral nutrition. J Plant Nutr 29: 1199-1206.

Antonova T. 2014. The history of interconnected evolution of Orobanche cumana Wallr. and sunflower in the Russian Federation and Kazakhstan. Proc. 3rd Int. Symp. on Broomrape (Orobanche spp.) in Sunflower, Córdoba, Spain. Int. Sunflower Assoc., Paris, France, pp. 57-64.

Buciuceanu M, Rotaru T, Lupashcu C, Lesanu E. 1994. Creation of initial material resistant to broomrape to sunflower breeding. Proc. Conf. dedicated to the 50 years of ICCC (1944-1994). Chisinau, Republic of Moldova, pp. 31-32.

Castejon-Munoz M, Romero-Manoz F, Garcia-Torres L. 1993. Effect of planting date on broomrape (Orobanche cumana Loefl.) infection on sunflower (Helianthus annuus L.). Weed Res 33: 171-176.

Cohen Y, Roei I, Blank L, Goldshtein E, Eizenberg H. 2017. Spatial spread of the root parasitic weed Phelipanche aegyptiaca in processing tomatoes by using ecoinformatics and spatial analysis. Frontiers Plant Sci 8: 973.

Dominguez J. 1996. Estimating effects on yield and other agronomic parameters in sunflower hybrids infested with the new races of sunflower broomrape. Proc. Symposium on Disease tolerance in Sunflower, Beijing, China. Int. Sunflower Assoc., Paris, France, pp. 118-123.

Duca M. 2015. Historical aspects of sunflower researches in the Republic of Moldova. Helia 38(62): 79-93.

Duca M, Glijin A, Lupascu V, Rotarenco V. 2009. Molecular screening of sunflower resistance to broomrape (Orobanche cumana Wallr.), race E. J Acad Sci Life Sci 3(309): 81-88.

Duca M, Clapco S, Cernolev E, Tapu L. 2015. Technological management in sunflower crop and expression of Orobanche cumana attack. Akademos 4: 75-83.

Duca M, Clapco S, Port A. 2016. Analysis of the soil parameters in the context of sunflower infection by Orobanche cumana Wallr. Sci Pap Agro Ser 59(1): 49-52.

Duca M, Acciu A, Clapco S. 2017. Geographical distribution and characteristics of $O$. cumana populations in the Republic of Moldova. J Acad Sci Mold Life Sci 2(332): 65-76.
Eizenberg H, Plakhine D, Hershenhorn J, Kleifeld Y, Rubin B. 2003. Resistance to broomrape (Orobanche spp.) in sunflower (Helianthus annuus L.) is temperature dependent. J Exp Bot 54 (385): 1305-1311.

Ephrath JE, Eizenberg H. 2010. Quantification of the dynamics of Orobanche cumana and Phelipanche aegyptiaca parasitism in confectionery sunflower. Weed Resist 50: 140-152.

Fernández-Martínez JM, Domínguez J, Pérez-Vich B, Velasco L. 2010. Update on breeding for resistance to sunflower broomrape. Helia 33(52): 1-12.

Gibot-Leclerc S, Corbineau F, Sallé G, Côme D. 2004. Responsiveness of Orobanche ramosa L. seeds to GR24 as related to temperature, oxygen availability and water potential during preconditioning and subsequent germination. Plant Growth Regul 43: 63-71.

Habimana S, Murthya KNK, Hattia V, Nduwumuremyib A. 2013. Management of Orobanche in field crops - a review. Sci J Crop Sci 2(11): 144-158.

Kasasian L. 1973. Miscellaneous observation on the biology of Orobanche crenata and Orobanche aegyptiaca. Proceedings of the European Weed Research Council on Parasitic Weeds, Malta. European Weed Research Council, Wageningen, the Netherlands, pp. 224-230.

Kaya Y. 2016. Sunflower. In: Gupta Sk, ed. Breeding oilseed crops for sustainable production. Cambridge: Academic press, pp. 55-88.

Kaya Y, Demerci M, Evci G. 2004. Sunflower breeding in Turkey for broomrape and herbicide resistance. Helia 27(40): 199-210.

Kinman ML. 1970. New developments in the USDA and state experiment station sunflower breeding programs. Proceedings of the 4th International Sunflower Conference, Memphis, TN, pp. 181-183.

Lechat MM, Pouvreau JB, Péron T, et al. 2012. PrCYP707A1, an ABA catabolic gene, is a key component of Phelipanche ramosa seed germination in response to the strigolactone analogue GR24. $J$ Exp Bot 63(14): 5311-5322.

Leclercq P. 1969. Une sterilité mâle cytoplasmique chez le tournesol. Ann Amelior Plant (Paris) 19: 99-106.

Leclercq P. 1971. La stérilité mâle cytoplasmique du tournesol. 1. Premières études sur la restauration de la fertilité. Ann Amelior Plant (Paris) 21: 45-54.

Louarn J, Boniface MC, Pouilly N, et al. 2016. Sunflower resistance to broomrape (Orobanche cumana) is controlled by specific QTLs for different parasitism stages. Frontiers Plant Sci 7: 590 .

Lyra D, Kalivas D, Economous G. 2016. A large-scale analysis of soil and bioclimatic factors affecting the infestation level of tobacco (Nicotiana tabacum L.) by Phelipanche species. Crop Prot 83: 27-36.

Maširevic S, Medic-Pap S. 2009. Broomrape in Serbia from its occurrence till today. Helia 32 (51): 91-100.

Mauromicale G, Restuccia G, Marchese M. 2001. Soil solarization. A nonchemical technique for controlling Orobanche crenata and improving yield of faba bean. Agronomie 21(8): 757-765.

Miladinovic D, Cantamutto M, Vasin J, Dedic B, Alvarez D, Poverene M. 2012. Exploring environmental determinants of the geographic distribution of broomrape (Orobanche cumana Wallr.). Helia 35(56): 79-88.

Mohamed KI, Papes M, Williams R, Benz BW, Reterson AT. 2006. global invasive potential of 10 parasitic witch weeds and related Orobanchaceae. AMBIO: J Hum Environ 35(6): 281-288.

Molinero-Ruiz L, Delavault Ph, Pérez-Vich B, et al. 2015. History of the race structure of Orobanche cumana and the breeding of sunflower for resistance to this parasitic weed: A review. Spanish J Agric Res 4(13): 1-19. 
Nandula VK. 1998. Selective control of Egyptian broomrape (Orobanche aegyptiaca Pers) by glyphosate and its amino acid status in relation to selected hosts. In: Thesis of Doctor of philosophy plant pathology, physiology and weed science thesis, University of Blacksburg, Virginia, p. 311.

Nandula VK, Foy CL, Westwood JH. 1996. Environmental influences on germination of Orobanche. In: Moreno MT, Cubero J, Berner D, Joel D, Musselman LJ, Parker C, eds. Advances in Parasitic Plant Research. Proceedings of the 6th International Symposium on Parasitic Weeds, Cordoba, Spain, pp. 411-416.

Rotarenco V. 2010. Morpho-physiological and genetic aspects of host-parasite interaction (Helianthus annuus L.-Orobanche cumana Wallr.). In: Summary of doctoral thesis, State University of Moldova, Chisinau, p. 26.

Sharova PG. 1977. Broomrape-sunflower parasite. Chisinau: Ed. Cartea Moldoveneasca.
Škoric D. 2016. Sunflower breeding for resistance to abiotic and biotic stresses. In: Shanker AK, Shanker C, eds. Abiotic and biotic stress in plants - Recent advances and future perspectives. Rijeka (Croatia): InTech Publisher, pp. 587-635.

Song WJ, Zhou WJ, Jin ZL, et al. 2005. Germination response of Orobanche seeds subjected to conditioning temperature, water potential and growth regulator treatments. Weed Res 45: 467-476.

Spallek T, Mutuku M, Shirasu K. 2013. The genus Striga: a witch profile. Mol Plant Pathol 14(9): 861-869.

Sukno S, Fernandez JM, Melero Vara JM. 2001. Temperature effect on the disease reactions of sunflower to the infection by Orobanche cumana. Plant Dis 85: 553-556.

Vear F. 2016. Changes in sunflower breeding over the last fifty years. OCL 23(2): D202.

Vronschih M, Boincean B, Buciuceanu M. 2002. Sunflower: recommendations. Chisinau: ACSA ed.

Cite this article as: Duca M, Clapco S, Nedealcov M, Dencicov L. 2019. Influence of environmental conditions on the virulence and distribution of Orobanche cumana Wallr. in the Republic of Moldova. OCL 26: 3. 